\title{
JOSEPH DEVASAYAGEM ROYEPPEN (1871-1960): THE ANGLICAN, COLONIAL BORN POLITICAL ACTIVIST
}

\section{Kalpana Hiralal}

University of KwaZulu-Natal

hiralalk@ukzn.ac.za

\section{ABSTRACT}

This article documents the contributions of Joseph Royeppen, a colonial born Christian activist in South Africa at the turn of the century. Royeppen was a barrister, passive resister and a devout Christian. He was the first colonial born Indian to study law at Cambridge and played an important role in mobilising support for Indian grievances whilst in England. He participated in the first satyagraha campaign in South Africa and endured imprisonment. Yet in the vast corpus of historical literature on South Africans of Indian descent he is given minimal recognition. This paper seeks to rectify this omission by documenting his contributions to the first satyagraha campaign that occurred in the Transvaal between 1907-1911. Royeppen, in his fight against oppression and inequality, embraced multiple roles: an eloquent student, barrister, devout Christian, hawker, passive resister and labourer. He mediated among these varying roles and in the process highlighted not only strength in character but dignity in protest action. A colonial born Indian, he was highly critical of the colonial and British governments and challenged their attempts to deny citizenship rights to South Africans of Indian descent. Joseph Royeppen's narrative is significant because it highlights the role and contributions of colonial born Indians, in particular the educated elite, to the early political struggles in South Africa. In many ways, they were an important, influential and active constituency in South Africa's road to democracy.

Keywords: Joseph Devasayagem Royeppen;Anglican; political activist; satyagraha; Indian; South African; Christian

\section{UNISA $\cong$}




\section{INTRODUCTION}

By 1910 well over 150000 Indians were settled in South Africa. Their arrival both as indentured and free Indians changed the demographic landscape of South Africa. However, their presence as a settled community was met with resistance from colonialists who viewed the non-labouring Indian as a serious economic threat. Subsequently, colonial authorities in the British colonies of the Cape and Natal and the Afrikaners in the Boer Republic of the Transvaal and the Orange Free State (OFS) sought to restrict their mobility and economic freedom in their provinces. In the OFS Indians were barred from residing and trading. In Natal the trade, immigration and franchise laws seriously affected the Indian community from eking out a livelihood. In the Transvaal the political situation was aggravated by the Asiatic Registration Act and the Immigration Restriction Act of 1907, which compelled Indians to register as residents and restricted their mobility into the Transvaal. Subsequently the Indian community challenged the restrictive measures and embarked on the first satyagraha ${ }^{1}$ campaign (Bhana and Shukla-Bhatt 2011, 19$23)$. The restrictive legislation not only humiliated the Indian community as subjects of the British Empire, but also their rights as South African citizens. Resistance to this discriminatory legislation and later the apartheid laws became a characteristic feature of the Indian community. It was amongst these early resistance movements that activists such as Joseph Royeppen emerged. He showed strength in character, moral resilience and an unwavering faith in freedom and equality for all, irrespective of race, class and religion. As a colonial-born Indian he viewed South Africa as his home, and he fought tirelessly and steadfastly to protect his rights and those of his fellowman.

Yet, in the vast corpus of historical literature on South Africans of Indian origin, the role and contributions of Joseph Royeppen during the first satyagraha campaign between 1907-1911 - in which he played a significant role - has yet to be fully documented. The pioneering historical works of Bhana $(1985 ; 1997)$ Bhana and Pachai (1984) and Bhana and Brain (1990) on the early settlement of Indian immigrants have laid the conceptual and theoretical foundations for a later generation of scholars to widen their scope of analysis in the context of gender, mobility, identity and politics. Early political struggles by Indians have largely focused on the satyagraha campaigns between 1907-1913 and the 1913 campaign has largely dominated the political historiography (Bhana and Dhupelia 1981; Bhana and N. Shukla-Bhatt 2011; Beall and North-Coombes 1983; Govinden and Hiralal 2015; Hiralal 2010; Mongia 2006; Nayar 1989; Swan 1984). The first satyagraha campaign between 1907-1911, when examined, is analysed in the context of Gandhi's biographies, centred around his political leadership and spiritual development (Guha 2013; Lelyveld 2011; Tidrick 2006). Nayar (1989) in her voluminous work Mahatma Gandhi: Satyagraha at work, cites only a few Indian resisters while devoting a lengthy chapter to biographies of European sympathisers. The contributions of 
Royeppen in most of the above cited works are cursory, footnoted or overlooked. There is no major analysis of his contributions as an educated colonial born Indian or political activist. Similarly, studies on Christian Indian immigrants to South Africa have largely focused on their early arrival, settlement, demographic composition and their religious beliefs (Brain 1975; 1982; 1983; Buijs 1985). Biographical studies of Christian Indians in the satyagraha campaigns in South Africa have largely been absent. This article draws on the works of Bhana (2003) who highlights the need to 'find the voices of the people', thereby capturing the lost histories of individuals and communities. This article adopts a biographical approach, thereby seeking to rectify the gaps in the above cited political historiography. Biographies and historical analysis have been the subject of many recent scholarly works. Problems of conceptualisation and methodologies have been contested issues across disciplines (Ambrosius 2004, viii). Ambrosius has argued that biographies require 'historical objectivity' and an understanding of 'internal and external influences' that shaped and defined an individual's life (Ambrosius 2004, viii). Biographical approaches are not only a 'prism of history', but capture the reader's 'interest in the larger subject' (Leckie 2004, 2).

This article documents the role and contribution of Joseph Royeppen, an Anglican Christian, to the early political struggles in South Africa. It locates the narrative within the socio-economic and political environment of South Africa at the turn of the century and how it shaped and defined Royeppen's religiosity and political ideology. It also maps out Royeppen's political contribution in the context of the first satyagraha campaign - between 1907-1911 - during which he played a very significant role. At the onset of the campaign, Royeppen was studying overseas to become a barrister. On his return to South Africa, he headed the call of resistance and left his high profile job to challenge both the colonial and British government by flouting immigration and trading laws. He defiantly crossed the Transvaal border without a permit, engaged in hawking without a licence and courted imprisonment. As a colonial born Indian and a subject of the British Empire, he was steadfast in his belief that birth-right and not race should be a criterion for citizenship. His political ideology was defined by his strong Christian faith and his steadfast belief in the principles of equality and justice. Joseph Royeppen's narrative is significant for two reasons: firstly, it illustrates the early political activism by Christian Indians, colonial born Indians (descendants of indentured Indians born and settled in South Africa) and the educated elite; and secondly it highlights the intersections of faith and resistance in South Africa's road to democracy.

\section{EARLY LIFE}

Joseph Royeppen was born in Natal in 1871. His parents were Devasayagem and Catherine who had immigrated to Natal in 1865 from Madras on board the ship 
Arddeg. There is minimal information on his early life; suffice to state that his family were devout Christians. His parents lived in a wood and iron dwelling at the corner of Victoria and Brooke Street in central Durban. Devasayagem, a devout Christian, was keen on proselytising Christianity. His home became an important site for worship, frequented by many disciples. Joseph was raised and educated in Durban. He was an intelligent student and educated at the Model School where several of his class mates were Europeans. He passed the collective examination and was keen on continuing his study and subsequently sought admission to the local high school, but was refused entry. He then embarked on a 'self-help' programme and succeeded in passing the Natal Civil Service examination. Thirty candidates wrote this exam, 15 passed and Royeppen was placed among the top seven. Despite his outstanding achievement he was not offered an appointment in the civil service. Yet European candidates with weaker grades were appointed to the civil service. This was largely due to racial attitudes which were strongly embedded in colonial Natal and prevented any form of upward mobility of non-Europeans. Undeterred, Royeppen was determined to acquire a tertiary education and proceeded to England 'at the expense of every shilling in my family' (Indian Opinion, 1 January 1910). He was accepted at Cambridge University where he studied for eight years and graduated with a BA LLB with distinction. He also passed the Bar Final examination at Lincoln's Inn, becoming the first South African-born Indian barrister and graduate at a British university. On completion of his studies he returned to South Africa and joined the satyagraha struggle in the Transvaal in December 1909 (Indian Opinion, 1 January 1910).

Joseph Royeppen was a devout Christian and his faith had a lasting impact on his character, leadership and political ideology. He attended Church regularly and as a young boy was employed by St Aidan's Church in Durban as its first organist in 1899 (Lucia 2005, 161). Christianity had spread widely amongst the Indian community in Natal at the turn of the century. There were already established Church mission stations (such as the Roman Catholics and Wesleyan-Methodists), when the first indentured Indians arrived. For example, Father Sabon spearheaded the Roman Catholic Church in Durban in 1853 and Reverend R Stott the Wesleyan Mission in 1862. Many of these Christian mission stations established schools. For example in Durban Lancelot Parker Booth, an Anglican deacon was motivated by the need to alleviate the poverty and suffering of the poor in Durban. He subsequently established 'Mission Schools' in Durban in 1886. In 1887 St Aidan's Church in Alice Street was built (Gandhi Luthuli Documentation Centre, hereafter cited as GLDC, St Aidan's Mission Centenary Brochure 1883-1983, doc no 602/14). These schools became key centres of learning for many prominent Christian Indian families such as the Royeppens and Lazarus families (Vahed 2005, 118). Royeppen was an avid sportsman, and like many educated colonial born Indians, valued sport. Sport, he believed, dictated ethical and moral behaviour in mankind. It instilled discipline, a 
work ethic, group solidarity and respect for rules and regulations (Vahed 2005, 118) He wrote in 1912 that sport had a 'greater purpose' than winning:

The battles of England have been won on the playing fields of Eton. As yet there are little signs of our battles being won upon our playing fields of South Africa...so long as young men follow sports without eye or ear to their final value for us in this our adopted land of one continued struggle for honourable existence, but merely for the passing excitement and intoxication of the thing, our playing fields must continue to be, not the school and the training ground to higher calls of life and duty, but scenes of our sure damage and loss. (Vahed 2005: 118)

For Royeppen religious tolerance was a key to social harmony and sought to embrace all religions equally. For example, during Royeppen's stay at the Phoenix Settlement in Durban at the turn of the century, he became familiar with many Hindu hymns. Gandhi recalls Royeppen's favourite hymns from the Hindu scriptures, the Bhagvad Gita. Gandhi states:

In Phoenix (South Africa) we had our daily prayers in the same way as in Sābarmati (India), and Musalmans as well as Christians attended them along with Hindus...Joseph Royeppen's favourite hymn was Vaishnava Jana meaning: He is a Vaishnava (worshipper of Vishnu) who succours people in distress. He loved music, and once sang this hymn saying "Christian" in place of Vaishnava. The others accepted his reading with alacrity, and I observed that this filled Joseph's heart with joy. (Agarwal 1997, 400; Shukla-Bhatt 2015, 190)

\section{INDIAN AMBULANCE CORPS}

Racial attitudes and political inequities affected the lives of many non-Europeans in colonial Natal. For many it provided a platform for political activism. For Royeppen his faith did profoundly shape and define his social and political doctrine. As an Anglican he was guided by a strong commitment to bring about social change and alleviate the sufferings of the poor. At the outbreak of the Anglo-Boer War 1899-1902 (also known as the South African War), both Joseph and his older brother, Manikum, formed an integral part of the Volunteer Indian Ambulance Corps established by Gandhi. The war was fought between the Boers and the British over the Transvaal. Whilst Gandhi was sympathetic to the Boers, as a British subject he felt politically obligated to protect and defend the Empire and to demonstrate Indian loyalty to the Crown (CWMG 19 October 1899, vol. 2, 1897-1902, 316-317). He stated:

The motive underlying this humble offer is to endeavour to prove that, in common with other subjects of the Queen-Empress in South Africa, the Indians, too, are ready to do duty for their Sovereign on the battlefield. The offer is meant to be an earnest of the Indian loyalty. The number we are able to place at the disposal of the Authorities may appear to be small; but it probably represents twenty-five per cent of the adult Indian males in Durban that have received a tolerably good English education. (CWMG. 19 October 1899, vol. 2, 1897-1902, 316-317) 
Gandhi was also keen to dispel colonial perceptions that 'the Indian was a coward, incapable of taking risks or looking beyond his immediate self-interest' (City Coins Postal Medal Auction 64, 2013, 18). Gandhi subsequently began to recruit as many volunteers as possible for the Corps. The Corps constituted mainly Christian Indians and was 1100 strong with nearly 40 leaders. About 300 were free Indians and the rest constituted indentured Indians (CWMG 14 March 1900, vol. 2, 1897-1902, 342347). Gandhi recruited the Royeppen brothers into the Corps. Joseph at the time was a member of the Natal Indian Congress (NIC, which was established in 1894). He served as a clerk to Gandhi when he established his legal practice in Durban. Other members of the Corps were: H.L. Paul, A.H. Peters, R.K. Khan, P. Dhanjisha, P.C. Cooper, J.W. Godfrey, R. Baghwan, P. Peter, N.P. Dhunde, V. Lawrence, L. Gabriel, G.D. Harry, R. Govindoo, S. Shadrack, Ramtahal, J.D. Home, M.H. Nazar, P K. Naidoo, K. Singh, S.N. Richards, M.S. Lutchman Panday, J. Christopher, C. Stevens, J.L. Roberts, H.J. Jappie, J.S. Done, B. Gabriel, F. Lazarus and R. Moodley (The Natal Mercury, 25 October 1899). With the assistance of Rev. Dr Booth the Corps was trained in ambulance work and received medical certification of fitness for service on the frontlines. Dr Booth served as an inspiration to the young men in the Corps. His tireless humanitarian and evangelical work among the Indian community in Durban drew praises form Gandhi: 'We may say without exaggeration, that you have presented to us a pattern of an upright Englishman and a good gentle Christian who knows no distinction between Jew and Gentile' (GLDC, St Aidens Mission Centenary Brochure 1883-1983, p.6, doc no 602/14). The Corps was largely an auxiliary unit to serve outside the firing line. The unit served at conflict locations at Colenso, Spioen Kop and Vaalkrantz, carrying wounded soldiers from the field. The corps was later disbanded in February 1900. The bravery and tireless efforts of the Corps were applauded by local newspapers (CWMG 14 March 1900, vol. 2, 18971902, 342-347). The Natal Witness stated:

One hundred miles in five days may be accounted fairly good walking for a man unburdened with any weight but that of his own carcass and clothes. When the wounded have to be carried on stretchers for nearly half that distance, and the greater portion of the remainder is traversed by men laden with heavy kit, such marching, I think, will be acknowledged as very creditable work. Such is the feat lately performed by the Indian Ambulance Corps, and one that any body of men may be proud of. (CWMG 14 March 1900, vol. 2, 1897-1902, 346)

Sir John Robinson, the first Prime Minister of Natal, shared similar sentiments:

With reference to the part played by the Indian community during the crisis, I can only say that it redounds to the credit and patriotism of you all. Reasons which you can well understand forbade the employment of any but British troops in the battle-field. But whatever use could be made of your loyal ardour - what opportunity could be afforded to your eager desire to co-operate in the Empire's cause... was gladly agreed to by the authorities. Though you were debarred from actual service in the field, you were able to do excellent work in succouring the wounded. I cannot too warmly thank your able countryman, Mr Gandhi, upon his timely, 
unselfish and most useful action in voluntarily organising a corps of bearers for ambulance work at the front at a moment when their labours were sorely needed in discharging arduous duties which experience showed to be by no means devoid of peril. All engaged in that service deserve the grateful recognition of the community. (CWMG 14 March 1900, vol. 2, 1897-1902, 371)

The Indian community also rallied to the support of the Corps. For example, Indian merchants supplied large quantities of cigarettes, cigars, pipes and tobacco for the wounded and sick (CWMG 14 March 1900, vol.2, 1897-1902, 343-348).

\section{YEARS IN ENGLAND}

As alluded to earlier, Royeppen went to England to study for a law degree. Whilst studying abroad, the Indian community in the Transvaal spearheaded the first satyagraha campaign against the Asiatic Registration Act and the Immigration Restriction Act of 1907. Collectively the laws sought to restrict the mobility of Indians in the Transvaal. It allowed only the former Indian residents of the Transvaal to enter after passing a strict education test. In addition they were required to register under the Asiatic Registration Act. In 1906, prior to the law receiving royal sanction, a deputation headed by H.O. Ally and Gandhi went to London, on behalf of the Indian community, to address their grievances. Royeppen, together with other South Africans who were studying in London, followed the political movements of the Indians in the Transvaal and the London deputation 'with great interest'. Royeppen together with Messrs Ritch and Godfrey met Gandhi at Waterloo station in London. Royeppen and Godfrey, together with other South African students in London, sought to assist Gandhi and Ally by mobilising support for the Indian cause abroad. They subsequently made a representation to the British government comprising of five students: three Christians, one Hindu and one Muslim. Of the five, four were studying to become barristers and one a medical doctor. The names of the five students were: Royeppen; George V. Godfrey; J.W. Godfrey; A.H. Gool and S. Ruthnum Pather. Collectively they drafted and sent a letter titled Colonial Indians, Memorial to the Earl of Elgin, the Principal Secretary of State for the Colonies, dated 3 November 1906. The Memorial letter not only alluded to the unjust laws affecting the Indians in the Transvaal, but more significantly to the status and citizenship rights of colonial born Indians who identified South Africa as their home and not India: 'We are all of us either born or brought up in South Africa, and to us South Africa is more our home than India. Even our mother tongue is English, our parents having brought us up to speak that language from our infancy' (CWMG, 3 November 1906, vol. 5, 6 November 1905 - 3 November 1906, 484-486; Indian Opinion, 8 December 1906). Their 'chief anxiety' was 'regarding ourselves and persons placed in a position similar to our own' (Indian Opinion, 8 December 1906). They also raised pertinent 
issues regarding their qualifications and how the Asiatic Law Amendment Ordinance would impact on their ability to practise as barristers and doctors.

The net result of this disability would be that although the certificates we would receive on our being called to the Bar, or on our receiving the Medical Diploma, which would entitle us to carry on our professions in any part of the British Dominions on the production of those certificates and of evidence of good character, our diplomas or certificates would be valueless, so far as the Transvaal is concerned. (Indian Opinion, 8 December 1906)

Royeppen and his colleagues found it difficult to reconcile the logic of imperial policy in South Africa. As students they lived in a 'free atmosphere' in England where they were taught 'Bentham, Austin and other English writers whose names are a watchword for liberty and independence', yet in South Africa, British Indians were denied ordinary rights of citizenship as enjoyed by white settlers. For Royeppen and his colleagues the term or phrase 'British Indians' or 'British subject' was problematic as it had no meaning in the Transvaal for resident Indians. Nevertheless, Ally and Gandhi, whilst in London, addressed 100 members of Parliament and 50 Liberal members of Parliament, and they met the Prime Minister in support of their representations. A South Africa British Indian Committee (SABIC) was set up, with Lord Ampthill, former Governor of Madras as President, to defend the rights of Indians in South Africa. As a result of these efforts, the British Government withheld its approval to the Asiatic Ordinance. It warned the deputation that the Transvaal would receive self-government at the beginning of 1907 and might enact its provisions into law. It confidentially assured the authorities in the Transvaal that a law enacted by the elected legislature would receive Royal assent. Upon acquiring self-government the Transvaal passed the contested legislation.

Royeppen returned to South Africa on board the Tintagel Castle in September 1909 after eight years of studying in England. On arrival he was given an honorary welcome by the Durban Indian Society. The reception was held at JB Timols Hall and addressed by A.H. Paul (Indian Opinion, 25 September 1909). On arrival in Durban his commitment to the satyagraha struggle took precedence over his career as a barrister and family commitments. He did not register as an advocate and 'It was the terriblest wrench for him to leave his old mother. But she willingly spared him for the sake of the Motherland' (Indian Opinion, 1 January 1910). Instead he was motivated by a 'larger duty'; that of the satyagraha struggle.

\section{SATYAGRAHA IN THE TRANSVAAL}

Royeppen became actively involved in the satyagraha campaign in the Transvaal. According to Swan, both William Godfrey and Royeppen were young leaders who played 'an active role in the politics of the new Natal elite as well as the passive resistance campaign in the Transvaal' (Swan 1985, 11). His decision to enter the struggle was based on two principles: imperial citizenship and self-respect. The 
satyagraha campaign gave him an opportunity to test his own political and moral conscience. As a lawyer he understood the importance of obeying the laws of the country. As a devout Christian he was guided by his conscience to oppose laws that were discriminatory and unjust, that threatened his rights and those of his people as citizens. Religiosity was not only fundamental to his personal development but also to his political ideology. In a letter to the local newspaper, the Natal Mercury he clearly outlined the reasons for his decision to participate in the struggle:

The question arises whether I have acquired a sufficient status to exercise the fullest rights of British citizenship or whether the fact of my race and colour, ipso facto, denudes me of any status when confronted by the question of Imperial rights and privileges. To test the question, I hope to proceed to the Transvaal in a few days. I have no right of residence there whatsoever, according to the Transvaal laws, but, by the right of Imperial citizenship, I claim to enter and reside in any part of his Majesty's dominions. If I am imprisoned in the attempt to vindicate an Imperial right, I wish my imprisonment to serve as an unqualified protest against a condition which is repugnant to the first principle of the British Constitution, i.e., the inherent right of the subject to enter and reside in any portion within the jurisdiction of the Constitution. (Indian Opinion, 1 January 1910)

In December 1909 Royeppen, together with six other satyagrahis (individuals who participated in the satyagraha campaign), which included Gandhi, Samuel Joseph (headmaster of the Indian School at Seaview, Durban), David Andrew (clerk and interpreter), Manilal Gandhi (Gandhi's second son aged 17), Abdul Gafur Fajandar (acting Chairman of the British Indian Association and merchant) and Ramilal Singh (clerk) set off to the Transvaal in defiance of the Immigration Restriction Act of 1907. However, they failed to get arrested. On his arrival in Johannesburg Royeppen wrote a letter to the Transvaal Press outlining (like he did in the Natal Mercury) his reasons for defiance:

I, therefore, declined to recognise the Asiatic Registration Act, and yesterday entered the Colony under the general Immigration Act as a free-born subject of the Empire. I have entered simply and solely to make good an Imperial right, the inherent right of every bona fide subject of the Empire to enter and reside in any part of His Majesty's dominions, subject, of course, to the general laws of the country. I have not entered the Transvaal, nor have my companions, to establish a permanent residence, to "swamp the Colony" or to deprive another of his bread, but to vindicate a principle, in defence of which over 2,500 of my countrymen of all castes and creeds have suffered imprisonment. (Indian Opinion, 1 January 1910)

Indian Opinion was full of praise for Royeppen and his colleagues for crossing the Transvaal border 'unchallenged' stating: '... we heartily congratulate these gentlemen on their pluck, their love of the Motherland and their self-sacrifice' (Indian Opinion, 1 January 1910). However, Royeppen's participation in the satyagraha struggle was also symbolic in that it highlighted the politically active role played by the colonialborn Indians. Up until late 1910, the struggle was largely confined to the Transvaal 
and to Indians of 'passenger' Indian descent. The entry of Royeppen, Joseph, Andrews and Singh, to some extent gave the movement a new dimension. It demonstrated that colonial-born Indians could play a significant political role in South Africa. Many of the colonial-born Indians attended Christian mission schools and also embraced Christianity. Royeppen, like his colleagues, had displayed patriotism, courage and commitment and served as role models to the Indian community to fight against unjust laws. Indian Opinion noted: 'On colonial-born Indians depends the future of our race in South Africa. We hope that they will prove themselves worthy of the responsibility' (Indian Opinion, 1 January 1910).

On arrival in Johannesburg a welcome reception was given to Royeppen, Joseph, Andrews and Manilal Gandhi at the Hamidia Hall on 23 December 1909. At the meeting the following resolution was unanimously adopted: 'This meeting of the British Indian Association congratulates Mr Joseph Royeppen, Barrister-atlaw, and his companions on their courage in having entered the Transvaal in order to take part in the struggle for national honour' (Indian Opinion, 1 January 1910). Royeppen was honoured with another reception, hosted by the Tamil Benefit Society of Johannesburg. Royeppen's humility, his commitment and his quick response to join the struggle were applauded: 'It reflects the greatest credit on you that you have come to join the struggle that is going on here for the honour of our Motherland. You have just returned from England after a prolonged absence and left those who are near and dear to you' (Indian Opinion, 8 January 1910). Whilst in Johannesburg Royeppen visited satyagrahis such as Parsee Rustomjee and Nanalal Shah, who were serving sentences at Diepkloof Prison (Indian Opinion, 8 January 1910).

On failing to be arrested the first time, Royeppen sought alternative methods of resistance. He emulated Manilal Gandhi and 16-year old Mohan Manji Ghelani and tried to court arrest by hawking fruit in January 1910. He wore a hawker's costume and attracted much attention in President Street in the Transvaal. Manilial and Ghelani were arrested on 14 January and were sentenced to 10 days' hard labour with the option of a fine of 30 shillings (Indian Opinion, 22 January 1910). Royeppen's decision to court arrest through hawking was significant because he highlighted the dignity of manual labour and how it can be used as an alternative form of protest. In addition, he also highlighted how educated Indians could contribute constructively and significantly to the political struggle (Indian Opinion, 29 January 1910). Gandhi was impressed with Royeppen's commitment to the struggle and serving as a role model to the youth: 'The educated can take to hawking in the manner of $\mathrm{Mr}$ Royeppen. If they do so, they will have no difficulty in getting arrested, since people are now being arrested for hawking' (Indian Opinion, 29 January 1910, translated from Gujarati). In addition, Gandhi was also indirectly alluding to the greater role that educated Indians could play in the struggle. To some extent he was disappointed that the latter had not been more active: 
Let us turn to the educated Indians in the Transvaal. If they had joined the struggle in the right spirit, there would have been a different story to tell. The fight would have been over by now. But instead of doing that, they have gone in for luxuries, money and dissipation. As a result, the uneducated hawkers are beginning to give in and the fight is being prolonged. (Indian Opinion, 29 January 1910 translated from Gujarati)

Royeppen was eventually arrested for hawking. It would appear that some constables were hesitant to arrest him. He was taken to the police station and appeared before Magistrate Schuurman. The Magistrate expressed regret of passing an order of deportation on someone of Royeppen's calibre. Royeppen, undeterred, stated that he was there to 'suffer for his principle' (Indian Opinion, 29 January 1910). However, despite the deportation order, Royeppen together with Andrews and Joseph defiantly re-entered the Transvaal and were arrested and tried at Volksrust as prohibited immigrants and fined $£ 50$ or three months' imprisonment with hard labour. They opted for prison (Indian Opinion, 29 January 1910, 5 February 1910). On the eve of his imprisonment he made an appeal to his fellow Indians to keep the struggle alive:

For claiming what is our just due, I am today a prisoner deprived of home, friends and liberty. There is no need to tell you, my brothers, that I have not accepted this unhappy lot to gain some personal end. There is no need to tell you that an Indian son would not leave his aged mother, his only parent, and accept imprisonment, thereby hastening the end of all he has left in the world. No, friends, we are engaged in a national struggle, a struggle for the honour and respect of our greater and venerable mother, India, the sacred land which gave our earthly mother her birth. For the honour of Mother India it is that every Indian today is called upon to give up father, mother, wife and children, but if every Indian cannot obey the call, let the brother that realises the sacredness of the call respond with his whole heart and soul and stand as firm as a rock until victory is won. And I appeal, as a Tamil particularly, to my Tamil brothers to stand to the end. (Indian Opinion, 29 January 1910)

As a Christian he was making a strong call to men individually, to seek their own conscience, and that political choices reside with them. His appeal is also indicative of Royeppen's call for greater political cohesion and moral conscience amongst the Indian community.

Royeppen was imprisoned at Diepkloof prison in the Transvaal. Indian Opinion in its editorial note on 5 February 1910, stated that the likes of Royeppen, Andrews and Joseph's imprisonment demonstrated to the colonial government and the Indian community that for educated Indians 'the only place of honour in the Transvaal is the Diepkloof gaol, and that they have, by their action, strengthened the Passive Resistance struggle. They may, however derive this consolation that the Passive Resisters are serving the Government just as well as they are serving their countrymen' (Indian Opinion, 5 February 1910). 


\section{IMPRISONMENT}

In prison Royeppen, Andrews and Joseph were applauded for being model prisoners. According to Indian Opinion:

They have taken their imprisonment "extremely well" and "We congratulate him and his friends on the brave stand they are making..." Mr Royeppen and his companions have set to the young Indians in South Africa a brilliant and a noble example worthy to be followed. They have shown that true happiness lies not in gaining riches but in moulding character. We trust that the lead given by Mr Royeppen will infuse a new spirit into the colonial-born and other Indians who have their work cut out before them if they wish to take part in the making of the future South African nation. (CWMG vol. 11: 11 April, 1910 - 12 July, 1911, vol. 11: 35)

P.K. Naidoo, satyagrahi and fellow prisoner at Diepkloof, was equally proud of Royeppen's dedication and commitment to the struggle. Writing to Royeppen's mother he stated:

...Just a little before my release your son [Royeppen] requested me to write to you that you have no need to have any fear about him...He is enjoying his incarceration. As a matter of fact, I do not know how to praise him for his magnanimity. As a colonial myself, and one keenly interested in the passive resistance movement, I feel proud to write to you that it is a blessing to us colonials to have one like him to be our leader. (Indian Opinion, 5 March 1910)

Writing to Gandhi, Naidoo stated: 'Messrs Royeppen, Andrew, Samuel, Harilal, Sodha, Sorabjee, and all the other passive resisters are as cheerful and game as anyone would wish to be. As for Mr Royeppen, I have not sufficient words to praise him. I am sure he will turn out to be an excellent leader for the Colonials...' (Indian Opinion, 5 March 1910). Naidoo, who was in prison with Royeppen, informed Indian Opinion (5 March 1910) that Royeppen did all his work, including the "carrying of slop pails, with the utmost cheerfulness, telling his fellow-prisoners that he had not gone to jail to pose as a B.A. but to be a common labourer' (Indian Opinion, 5 March 1910). Indian Opinion commented: 'Of such will the resurrected Indian nation be made' (Indian Opinion, 5 March 1910). In prison Royeppen did not mind working as a common labourer and performing tasks assigned to him. His prison experiences were published in Indian Opinion under the title 'Indian Barrister's gaol experiences' (Indian Opinion, 7 May 1910). In his account Royeppen states that apart from defying the immigration laws of the Transvaal, he also wanted to 'experience in person the incidents of prison administration in the Transvaal, so far as they affect Indian prisoners' (Indian Opinion, 7 May 1910; CWMG vol. 11: 11 April, 1910 - 12 July, 1911, vol. 11: 35). His experiences are significant as they provide some insight into the nature and treatment of satyagrahis in prison (Indian Opinion, 7 May 1910). Like many satyagrahi prisoners at the time of arrest, Royeppen was treated harshly. Upon arrest he was transferred to Diepkloof prison in a manure cart and was forced 
to walk barefoot and bareheaded for nearly two miles. Royeppen and his fellow prisoners were not given breakfast on the day they were transferred (CWMG 23 February 1910, vol. 10, 5 August 1909- 9 April 1910, 425-427). He was treated like a common thief and handcuffed and subjected to verbal abuse:

An officer came to lock my hands, and, as he did so, he positively fumed with rage. $\mathrm{He}$ tightened the irons upon my wrist to such painful extent that I was compelled to apprise him of the fact. "I would like to tighten it round your neck", was the reply as he loosened the cuffs. He was able between gasps to express the wish that I with the rest of my countrymen, would be put aboard some derelict, put to sea and the bottom of the craft knocked off. Another boasting His Majesty's uniform came along and indulging in sundry invectives of the same order, marched us to a wagon that stood some way off. We reached the wagon over the sharp stones in funeral march time, but found mounting thereon difficult by reason of the prisoners being coupled. The wagon conveyed wet manure which oozed through the canvas upon which we sat. The stench was overpowering. Observing we were barefooted, the officer ordered the driver as follows: "Put the beggars down when you get out the town and make them walk the whole way to Diepkloof." We were driven through some of the principal streets of the town barefooted and bare-headed and ere long the sun began to tell upon our closely cropped heads. Out of town, we were made to jump out, but this was no small acrobatic feat for the need for the locked couple reaching terra firma simultaneously is obvious. For the first time I commenced a march barefoot and a two mile tramp over rough ground found the spirit willing but the flesh weak. Calling a halt we declared the predicament, boarded the wagon and were landed at the prison gates. Straightaway an official gave us a foretaste of what was in store for us. Eighteen hours we had gone without food, and were deaf and faint from the gnawings of hunger, when we were ordered to carry a muid of potatoes. Gamely we essayed a manifest impossibility when I detected the officer wink to a brother out of barbarous delight at our discomfiture. That was insult added to injury and we dropped the bag in resentment. (Indian Opinion, 7 May 1910)

\section{Prison food was unfit for human consumption:}

The prison-diet as follows: Breakfast at 6am, 8ozs mealie-meal; lunch 6 hours later, 6ozs rice and 6ozs vegetables; supper 5 hours after consists of 2 ozs mealie-meal and 4 ozs bread. That is to say 28ozs (raw weight) to live upon for 24 hours, 10 of which hours have to be devoted to hard labour. It will be observed that four-fifths of the Indian scale or more is comprised of farinaceous matter. The preponderance of mealie-meal stamps the diet as essentially a native one; but the native would reject the diet with scorn, for his own is an infinitely superior one, in that, while constituting his staple food, it is a great deal better than what he would revel in amid the scarcity of his native kraal. And the remarkable and all important difference in his favour is that while he gets an ounce of animal fat daily with his mealie-meal, a necessity and a luxury he does not enjoy at home, the Indian by some freak of administrative logic is not permitted the equivalent in the form of ghee, which is an absolutely essential part of his diet at home. No rational being would vote either the Indian or the native scale as anything approaching a sufficient common-sense allowance to produce ten hours of pick shovel or harrow work. (Indian Opinion, 7 May 1910) 
Royeppen's account not only exposed the harshness of prison conditions, but also significantly illuminated the courage and tenacity of imprisoned satyagrahis. However, despite the harsh treatment it did little to unnerve their commitment, on the contrary it strengthened their resolve to resist. Indian Opinion applauded the efforts of Royeppen and stated:

We congratulate this barrister-passive resister, hawker and labourer upon his unique experiences. His presence in the gaol has been a matter of encouragement and of education to his fellow-prisoners. By his intense desire to share in the fullest measure the hardships of his co-prisoners he has endeared himself to them, and by his unfailing good humour and the philosophic calmness with which he has gone through his experiences he has greatly strengthened his fellow resisters. Mr Royeppen's evolution has astonished his friends, and we believe equally the authorities. At first it was considered that he, who has been the pet of his family, has been softly nurtured, and has had a pleasing experience for a number of years of English life, would not be able to stand the rough life of an Indian convict, especially during the trying winter months of the Transvaal. No such fear is now entertained by the community...Mr Royeppen found himself in harness immediately on his discharge. He has gone to Tolstoy Farm and is there working like a common labourer - minding nothing. He takes his hand at wood chopping, water carrying, loading and offloading, laundry work - in fact, every form of what is generally termed menial work. His good humour never fails him in all he does. And he fills his companions with joy by wearing a pleasant smile on his lips even when he is doing the hardest work to which he is not accustomed. (Indian Opinion, 9 July 1910)

Royeppen was released in July 1910 and thereafter went to Tolstoy Farm. The farm was situated on the Vereeniging line 222 miles from Park Station, Johannesburg, and the nearest station being Lawley. The farm of nearly 1100 acres was purchased by Hermann Kallenbach (Indian Opinion, 9 July 1910; 18 June 1910). On the farm Royeppen worked as a common labourer engaging in tasks such as chopping, carrying water and laundry work (Indian Opinion, 9 July 1910). The farm was an important retreat centre for many satyagrahis and their families during the strike and was supported by the local community. For example, in February 1911 Appasamy Nayager supported the school on the farm by donating pencils and books; Johnny Peters sent three cricket bats; G.R. Maurice one basket of grapes; A.A. Moodley three boxes of grapes and R.K. Naidoo and several Tamil-speaking Indians supplied watermelons (Indian Opinion, 11 February 1911). Royeppen continued to court imprisonment and was sentenced to six weeks with hard labour in May 1910; three months with hard labour in July 1910 (Indian Opinion, 3 September 1910). Royeppen was imprisoned with other satyagrahis such as D. Murugan, Thambi Naidoo, Veera Francis and Pragji Desai at Diepkloof. Prison treatment fared no better. They were ordered to strip and refused to do so. They were subsequently punished with solitary confinement and a spare diet for 24 hours (Indian Opinion, 8 October 1910). At the end of October 1910, Royeppen, D. Murugan, Veera Francis and Pragji Desai were discharged from Diepkloof. Royeppen was appalled at the treatment of fellow 
satyagrahis such as Veerasamy and Moorgan (Indian Opinion, 8 October 1910; 29 October 1910). For example, Albert Veerasamy complained to the doctor of chronic convulsions but the latter refused to adhere to the complaints. David Moorgan too complained to the doctor of pain and swelling in the ankles. The doctor ignored his pleas but the chief warder took it seriously and he was granted labour reprieve for a fortnight (Indian Opinion, 29 October 1910).

In early January 1911 Royeppen continued to court arrest and was imprisoned for three months with hard labour at Diepkloof. He was released on 17 April together with Chinese passive resister Leung Quinn. Amongst those present to receive them were Thambi Naidoo, Harilal Gandhi, and Samuel Joseph (Indian Opinion, 1 April 1911; 15 April 1911). In May 1911, in the midst of the final negotiations between Smuts and Gandhi on the satyagraha grievances, a soccer match was held in the Transvaal honouring both Royeppen and Thambi Naidoo. A group of enthusiastic sportsmen (many of whom were satyagrahis) formed two soccer teams of which one was called the 'Bande Mataram League'. Royeppen was given the title of 'Patron of the Bande Mataram League'. Naidoo's team wore dark green jerseys and white shorts while Royeppen's team wore red and blue flannel and black shorts. Naidoo's team won the toss and won the friendly match. (Indian Opinion, 13 May 1911)

After his release from prison in 1911, Royeppen continued to engage in protest movements. In June 1911 during the coronation of the British sovereign, Indians were not particularly enthusiastic about being part of the festivities as the grievances of the Indians in the Transvaal had not been fully addressed. The Durban Town Council tried to elicit support from the Natal Indian Congress (NIC) but the latter replied that in view of the struggles of the Transvaal Indians and the disabilities imposed on their movements, they could not participate in the festivities. However, they argued that they would only join the festivities provided there was 'equality of opportunity and treatment guaranteed with the European celebrants'. However, the Congress received no reply from the Town Council (Indian Opinion, 24 June 1911). The Town Council was not to be dissuaded. Instead, through the European master of the Indian market they advertised sports and pastimes for farmers, market-gardeners and stall-holders which were to be held on the Berea flats. This was an indirect method of the Town Council to coerce local Indians to be part of the coronation festivities. The Council also contributed $£ 50$ to this event. Royeppen was appalled at the actions of the Council and in a letter to the Natal Mercury stated that the measure was nothing but a "clever ruse on the part of the Town Council to involve the name of the community thereafter as having taken part in the general celebrations, after degrading a humble section of them in this manner...have organised a body of pickets of their best men, 100 strong, to do duty on that day, and take up convenient beats to warn all unsuspecting Indians of the true nature of these proceedings...' (Indian Opinion, 24 June 1911). After the satyagraha campaign Royeppen returned to Durban in 1912 and practised law and continued his community and evangelical 
work. He was active in politics, youth development and wrote avidly to the media regarding the treatment of Indians in South Africa. Royeppen, whilst an ardent admirer of Gandhi, was highly critical of Indian Opinion, the newspaper founded by Gandhi in 1903. He stated that Indian Opinion was not interesting to Indian youth and suggested format changes: "As it is I hardly ever see a boy with Indian Opinion in his hand simply because there is nothing specially for him there to raise his curiosity, interest or criticism. He only knows that 20 out of 24 pages are Gujerati and he wants to know what all that Gujerati stuff is about!' (Mesthrie 1997, 113).

Royeppen also served on several community organisations. He was secretary of the Durban Reception Committee for Gokhale on his visit in 1912. He later moved to the Transvaal and became a member of the British Indian Association (BIA). When the South African Indian Congress (SAIC) was established in May 1923 he was elected to its council as one of the three representatives of the British Indian Association. He was elected by Madras Presidency as one of its delegates to the Nagpur Congress in 1921 to represent Transvaal Indians and visited Gandhi's Ashram at Sabarmati. He died in June 1960.

\section{CONCLUSION}

Royeppen's biographical narrative highlights two issues. Firstly the tenacity and courage of colonial-born Indians and their contributions to the freedom struggle in South Africa. Colonial-born Indians, despite their educated and professional status, were not afraid to heed the call for resistance. Engaging in manual labour (hawking, washing clothes and ironing) and courting imprisonment were tasks they willingly embraced. Secondly, it also highlights the role of religiosity in shaping and defining political ideologies. Royeppen's Christian beliefs, which were firmly entrenched at a young age, moulded his thoughts and actions. Individual free will, freedom and non-racialism were, for Royeppen, central tenets of the Christian faith. He sought to bring about social change through non-violent means and in so doing served as a role model to the youth as a political activist and Christian. Indian Opinion aptly stated: 'Mr Royeppen and his companions have set to the young Indians in South Africa a brilliant and a noble example worthy to be followed' (Indian Opinion, 7 May 1910). Many later political activists were to follow in Royeppen's footsteps.

\section{NOTE:}

1. Satyagraha, a non-violent campaign spearheaded by Indians in South Africa (19071913) against economic and political disabilities. 


\section{REFERENCES}

Agarwal, S.P. 1997. The social role of the Gita: How and why. Delhi: Motilal Banarsidass Publishers.

Ambrosius, L.E. (Ed.). 2004. Historians and their craft. Lincoln and London: University of Nebraska Press.

Beall, J. and North-Coombes, D. 1983. The 1913 Natal Indian strike: The social and economic background to passive resistance. Journal of Natal and Zulu History, vi: 48-81.

Bhana, S. 1985. Indian trade and traders in colonial Natal. In Enterprise and exploitation in a Victorian colony in Natal: Aspects of the economic and social history of colonial Natal. Edited by B. Guest and J.M. Sellers. Pietermaritzburg: Natal University Press.

Bhana, S. 1997. Gandhi's legacy: The Natal Indian Congress, 1894-1994. Pietermaritzburg: University of Natal Press.

Bhana, S. 2003. The present in the past: Indian experience 1860-1914. The Oriental Anthropologist 7(1): 176-186.

Bhana, S. and Brain, J. 1990. Setting down roots: Indian migrants in South Africa 1860. Johannesburg: Witwatersrand University Press.

Bhana, S. and Dhupelia, U. 1981. Passive resistance among Indian South Africans. Unpublished paper presented to the conference of the South African Historical Association, University of Durban-Westville, July 1981.

Bhana, S. and Pachai, B. 1984. A documentary history of Indian South Africans. Cape Town: David Philips.

Bhana, S. and Shukla-Bhatt, N. 2011. A fire that blazed in the ocean: Gandhi and the poems of Satyagraha in South Africa, 1909-1911. New Delhi: Promilla \& Co.

Brain, J.B. 1975. Catholic beginnings in Natal and beyond. Durban: TW Griggs \& Co.

Brain, J.B. 1982. Catholics in Natal II 1886-1925. Durban: Archdiocese.

Brain, J.B. 1983. Christian Indians in Natal 1860-1911: A historical and statistical study. Cape Town: Oxford University Press.

Buijs, G.C.V. 1985. A study of Indian Pentecostal membership with reference to model of religious change. $\mathrm{PhD}$ thesis. University of Cape Town.

City Coins Postal Medal Auction 64, 2013: 18.

CWMG: Collected Works of Mahatma Gandhi, vol. II, 1897-1902. (New Delhi, The Director, The Publications Division).

Gandhi Luthuli Documentation Centre, GLDC, Westville Campus, University of KwaZulu-Natal, St Aidans Mission Centenary Brochure 1883-1983, doc no 602/14.

Govinden, B. and Hiralal, K. (Eds). 2015. Satyagraha: Passive resistance and its legacy. New Delhi: Manohar.

Guha, R. 2013. Gandhi before India. London and New Delhi: Penguin.

Hiralal, K. 2010. Rethinking gender and agency in the Satyagraha Movement of 1913. Journal of Social Sciences 25: 71-80.

Indian Opinion, 8 December 1906. Colonial Indians' memorial.

Indian Opinion, 25 September 1909. Notes on the struggle.

Indian Opinion, 1 January 1910. Mr Royeppen's credentials. 
Indian Opinion, 8 January 1910. Transvaal notes.

Indian Opinion, 22 January 1910. Transvaal notes.

Indian Opinion, 29 January 1910. From the editor's chair.

Indian Opinion, 5 February 1910. From the editor's chair.

Indian Opinion, 5 March 1910. Mr Joseph Royeppen and his fellow prisoners.

Indian Opinion, 7 May 1910. Indian barrister's gaol experiences.

Indian Opinion, 18 June 1910. From the editor's chair.

Indian Opinion, 9 July 1910. From the editor's chair and Transvaal notes.

Indian Opinion, 3 September 1910. Transvaal notes.

Indian Opinion, 8 October 1910. Prison treatment of passive resisters.

Indian Opinion, 29 October 1910. Transvaal notes.

Indian Opinion, 11 February 1911. Transvaal notes.

Indian Opinion, 1 April 1911. Transvaal notes.

Indian Opinion, 15 April 1911. Transvaal notes.

Indian Opinion, 13 May 1911. Transvaal notes.

Indian Opinion, 24 June 1911. Coronation day in Durban.

Leckie, S.A. 2004. Biography matters: Why historians need well-crafted biographies more than ever. In Writing biography: Historians and their craft. Edited by E.A. Lloyd. Lincoln and London: University of Nebraska Press.

Lelyveld, J. 2011. Great soul: Mahatma Gandhi and his struggle with India. New York: Alfred A Knopf.

Lucia, C. (Ed.). 2005. The world of South African music: A reader. Newcastle: Cambridge Scholars Press.

Mesthrie, S.U. 1997. From advocacy to mobilization. Indian Opinion, 1903-1914. In Voices of protest and resistance, $1880 \mathrm{~s}-1860 \mathrm{~s}$. Edited by L. Switzer. Cambridge: Cambridge University Press, p. 99-128.

Mongia, R. 2006. Gender and the historiography of Gandhian Satyagraha in South Africa. Gender and History, 18: 130-149.

Nayar, S. 1998. Mahatma Gandhi, Volume IV: Satyagraha at work. Ahmedabad: Navajivan Publishing House.

Shukla-Bhatt, N. 2015. Narasinha Mehta of Gujarat:A legacy of Bhakti in songs and stories. New York: Oxford University Press.

Swan, M. 1984. The 1913 Natal Indian strike. Journal of Southern African Studies, 10: 239-58.

Swan, M. 1985. Gandhi: The South African experience. Johannesburg: Ravan Press.

The collected works of Mahatma Gandhi, vols. II-XI. 1962. Ahmedabad: Navajivan Press.

The Natal Mercury, 25-10-1899.

Tidrick, K. 2006. Gandhi: A political and spiritual life. London: I.B .Taurus.

Vahed, G. 2005. Deconstructing 'Indianness': Cricket and the articulation of Indian identities in Durban, 1900-32. In Ethnicity, sport, identity - struggles for status. Edited by J.A. Mangan and A. Ritchie. London: Routledge. 